\title{
デンマークの学校における英語の授業活動とセッティングのシステム ENGLISH LESSON ACTIVITIES AND SYSTEMS OF SETTINGS IN DANISH SCHOOLS
}

\author{
立花美 緒*1, 安田幸一*2, 宮本文人*3 \\ Mio TACHIBANA, Koichi YASUDA and Fumihito MIYAMOTO
}

\begin{abstract}
This study investigated English lessons and physical settings at ten schools in Denmark. First, English education and space used in English lessons were examined by interviews with teachers. Next, behavior observations of students and teachers in English lessons were conducted. Teachers are found considering that adequate open spaces have good effects on English lessons, especially speaking English and group works. The characteristics of the fifteen English lessons were clarified through exploring the relationship of contents, activities, and systems of settings.
\end{abstract}

Keywords: English Education, Learning Environment, Denmark, Comprehensive School, Upper Secondary School 英語教育, 学習環境, デンマーク, 小中一貫校, 高等学校

\section{1. はじめに}

\section{1-1. 研究の背景}

「主体的・対話的で深い学び」や高大接続改革を掲げた新学習指 導要領が、2020 年度より順次実施されている ${ }^{12) 33}$ 。中でも外国語 教育は、小学校から高等学校までの一貫した学びを重視し、高等学 校においては「聞くこと」「読むこと」「話すこと」「書くこと」の 4 技能をバランスよく育成することになった。大学入学共通テスト についても、民間事業者の活用は延期になったものの、4 技能を重 視する方針は変わらず、外国語教育は大きな変革を求められてい る。外国語教育の中でも英語は多くの学校で採用されており、新し い授業で必要とされる教育環境を検討することは急務である。

国別 TOEFL スコアが 4 技能ともに高水準にあるデンマークでは4)、 1970 年代から生徒中心の学習プロセスは、生徒をやる気にさせる だけでなく社会性や交流する力を育み、専門知識や洞察力と同様も しくはより重要であるという考えが生まれ、多様な学習形態が導入 されてきた ${ }^{5)}$ 。うしたデンマークの学校における英語の授業活動 と利用場所の関係を検討寸ることは、今後の日本における英語教育 のための空間計画にも、示唆を与えるものと考えられる。また、英 語の授業は語学の習得という性質により、対話やペアワーク（以下 $\mathrm{PW}$ )、グループワーク ( 以下 GW) 等、幅広い授業形態が導入されや すく、多様な学習活動が凝縮して観察できると考えられ、他教科を 含めて「主体的・対話的で深い学び」を支える教育空間を検討する 上でも、参考になることが期待される。

\section{1-2. 既往研究}

デンマークの学校建築の主な研究として、伊藤 $(2001,2004)$ は、
公立小中学校にあたるフォルケスコーレを対象に、学習活動と空間 の使われ方 ${ }^{6)}$ とオープンプランの変容 ${ }^{7)}$ について考察している。筆 者ら（2020）は、普通科高等学校にあたるギムナジウムについて、校 舎の中心に位置する内部広場（以下コモンコア）の空間構成と使わ れ方を分析している ${ }^{8)}$ 。英語教育と空間利用に関する研究として、 宮本ら（2009）は、国内の小学校における英語活動の教室利用と授 業展開を研究しており ${ }^{9)}$ 、新学習指導要領を実施する前の調查であ るが、分析の手法は参考になる。森田、柳澤 $(2009,2011)$ は、英語 イマージョンプログラムを実践する学校において、学年、教科別の 空間利用に関して分析している ${ }^{10011)}$ 。学校における空間の使われ方 については多くの研究があるが、倉斗ら（1999）は、小学校におけ る児童の 1 日の活動の場所について分析している ${ }^{12)}$ 。ラポポート （2005）は、環境の比較手法として、ある活動システムが行われる いくつものセッティングから成るシステム全体（以下セッティング

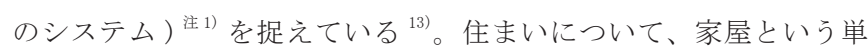
位で比較するのではなく、街路、喫茶店等の近隣も含めた活動が及 ぶ範囲全体を、諸セッティングの集まったシステムとして定義して いる。本稿では、建築物の用途は異なるがその概念を参考にし、教 室という単位を比較するのではなく、先ず英語の授業活動が及んで いる範囲を捉え、セッティングのシステムを分析する。

\section{1-3. 研究の目的}

日本の英語教育は変革が求められているが、今後の英語教育を支 える学校建築の計画を明らかにした既往研究は見当たらない。そこ で本稿は、1970 年代から多様な学習形態が導入されてきたデンマー クの学校を対象に、英語授業の内容とセッティングのシステムの関
*1 東京工業大学環境 - 社会理工学院 助教 - 修士 (工学)

*2 東京工業大学環境 · 社会理工学院 教授·博士 (学術)

*3 東京工業大学 名誉教授. 工博
Assist. Prof., School of Environment and Society, Tokyo Institute of Technology, M.Eng. Prof., School of Environment and Society, Tokyo Institute of Technology, Ph.D. Prof. Emeritus, Tokyo Institute of Technology, Dr.Eng. 
係を検討し、日本の学校における今後の英語教育で、既存のどのよ うな空間等を役立てることができ、新たに整備する必要があるか、 予察を得ることを目的とする。具体的には、デンマークの学校制 度と調查の概要を述へ (2 章) 、英語の授業内容と利用している場 所の概況（3 章）と、その実態及び空間と物的要素 (4 章) を捉え、 英語の授業活動とセッティングのシステム（5 章）を把握する。

\section{2. デンマークの学校制度と調査概要}

\section{2-1. デンマークの学校制度}

デンマークの教育制度は、0 学年のプレスクールと 9 学年の小 中学校にあたるグルンドスコーレの 10 年間が義務教育で (Fig. 1)、 公立小中学校はフォルケスコーレと呼ばれる。9 学年終了後、10 学年として 1 年延長することも選択できる。ギムナジウムと呼ば れる普通科高等学校では、2005 年のギムナジウム教育改革以降、 入学後の数ヶ月間は共通の課目を学び、その後自然科学、社会学、 言語学、芸術学等の系列を選択する。1 学級の最大の児童生徒注2) 数は、フォルケスコーレ、ギムナジウムともに 28 人である注 314115)。 フォルケスコーレとギムナジウムの学校建築の変遷については、文 献 6、8 に概略が述べられているので参照されたい。

\section{2-2. 対象校の概要}

調査対象とする学校種は、フォルケスコーレとギムナジウムとす る。日本の新学習指導要領の外国語教育では、小学校から高等学校 までの一貫した学びを重視しており、本稿においても、デンマーク の初等教育から中等教育を通じて、授業活動とセッティングのシス テムの関係を検討し、特徵を捉えることを試みる。デンマークの建 築専門誌注 (4) に掲載された学校から、授業活動とセッティングのさ まざまな関係を検討するために、空間や物的要素に特徵がみられ るフォルケスコーレ 5 校とギムナジウム 5 校の計 10 校を選定した。 対象校の概要を示寸 (Table 1)。校舎の建設年は 1930 年代から 2010 年代まで幅広いが、いずれも調查時点から 10 年以内に改修もしく は新築されている。

各学校の平面図を示し (Fig. 2)、特徴を以下に述べる。フォルケ
Age of pupils

$\begin{array}{llllllllllllllllllllllllll}0 & 1 & 2 & 3 & 4 & 5 & 6 & 7 & 8 & 9 & 10 & 11 & 12 & 13 & 14 & 15 & 16 & 17 & 18 & 19 & 20 & 21 & 22 & 23 & 24 & 25\end{array}$ Vuggestue日ørnehave $L$
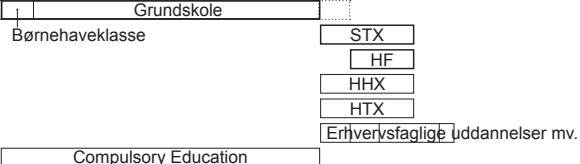

Fig.1 Edcation system in Denmark$$
\text { Free Education }
$$

Table1 Sample schools

\begin{tabular}{|c|c|c|c|c|c|c|c|c|c|c|c|}
\hline Sample & schools & KS & HS & NS & AS & FS & SG & GG & HG & NG & $O G$ \\
\hline \multirow{4}{*}{ Survey } & Visited & 3.2017 & 12.2015 & 3.2017 & 3.2017 & 3.2017 & 12.20151 & 12.2015 & 12.2015 & 12.2015 & 512.2015 \\
\hline & $\begin{array}{l}\text { Respondents } \\
\text { to interview or } \\
\text { questionnaire }\end{array}$ & 1 & 2 & 1 & 1 & 1 & 2 & 3 & 4 & 1 & 2 \\
\hline & $\begin{array}{l}\text { Observed } \\
\text { lessons }\end{array}$ & 1 & 0 & 2 & 3 & 1 & 3 & 2 & 1 & 1 & 1 \\
\hline & Weather & $\begin{array}{l}\text { Cloudy } \\
\text { / rainy }\end{array}$ & Cloudy & $\begin{array}{l}\text { Cloudy } \\
\text { / rainy }\end{array}$ & Sunny & Cloudy & $\begin{array}{l}\text { Cloudy } \\
\text { / rainy }\end{array}$ & Sunny & Cloudy & Sunny & Cloudy \\
\hline \multirow{6}{*}{ School } & Type*1 & $\mathrm{F}$ & $\mathrm{F}$ & $\mathrm{F}$ & $\mathrm{F}$ & $\mathrm{F}$ & G & G & G & G & G \\
\hline & $\begin{array}{l}\text { Completion, } \\
\text { and resent } \\
\text { refurbishment }\end{array}$ & $\begin{array}{l}1933, \\
2002, \\
2017 \\
\end{array}$ & $\begin{array}{l}2002 \\
2011\end{array}$ & 2012 & 2016 & 2016 & $\begin{array}{l}1980, \\
2000, \\
2014\end{array}$ & $\begin{array}{l}1981, \\
2007\end{array}$ & $\begin{array}{l}1981, \\
2006, \\
2015\end{array}$ & $\begin{array}{l}2003, \\
2015\end{array}$ & 2007 \\
\hline & Location & Urban & Urban & Rural & Rural & Urban & Rural & Suburb & Urban & Suburb & Urban \\
\hline & Students & 941 & 647 & 932 & 1,057 & 908 & 525 & 615 & 588 & 1,092 & 1,177 \\
\hline & $\begin{array}{l}\text { Aboveground } \\
\text { stories }\end{array}$ & 3 & 3 & 2 & 2 & 4 & $2^{*} 2$ & 2 & 2 & 4 & 5 \\
\hline & Floor area & $6,000 * 3$ & 8,200 & 13,500 & 12,000 & $14,833^{*} 4$ & 10,000 & 11,500 & 10,500 & 16,000 & $12,000 * 5$ \\
\hline
\end{tabular}

\section{Table2 Survey overview}

Sample schools 5 folkeskole and 5 gymnasium, published in architectural magazines in Denmark Resource acquisition Drawings, such as plans and sections, and building information were collected from architectural magazines, architectural design firms, or schools directly or through the websites.
School information, such as the number of students, was collected from the schools,
states, the government directly or through their websites.

\begin{tabular}{ll} 
& $\begin{array}{l}\text { School information, such as the number of students, was collected from the schools, } \\
\text { states, the government directly or through their websites. }\end{array}$ \\
\hline Visited & $12-2015$ and 03-2017 \\
\hline Visiting survey & $\begin{array}{l}\text { Interviewed teachers on English lessons*1 } \\
\text { Verified actual situation furniture and space, which is used in English lessons } \\
\text { Observed students' and teachers' behavior in English lessons }\end{array}$ \\
\hline \multirow{2}{*}{1 send }
\end{tabular}
*1 Send emails to some of them later to ask questions, too.

\section{Table3 Sample lessons}

\begin{tabular}{|c|c|c|c|c|c|c|c|c|c|c|c|c|c|c|c|}
\hline Lesson & KS1 & NS1 & NS2 & AS1 & AS2 & AS3 & FS1 & SG1 & SG2 & SG3 & GG1 & GG2 & HG1 & NG1 & OG1 \\
\hline Type $^{* 1}$ & $\mathrm{~F}$ & $\mathrm{~F}$ & $\mathrm{~F}$ & $\mathrm{~F}$ & $\mathrm{~F}$ & $\mathrm{~F}$ & $\mathrm{~F}$ & G & G & G & G & G & G & G & G \\
\hline Grade & 9 & 5 & 5 & 3 & 6 & 7 & 6 & 1 & 1 & 2 & 1 & 2 & 1 & 1 & 2 \\
\hline Students & 21 & 23 & 23 & 23 & 23 & 21 & 24 & 28 & 22 & 26 & 23 & 22 & 23 & 29 & 22 \\
\hline Boys & 11 & 15 & 12 & 12 & 12 & 12 & 15 & 12 & 5 & 13 & 11 & 12 & 12 & 19 & 6 \\
\hline Girls & 10 & 8 & 11 & 11 & 11 & 9 & 9 & 16 & 17 & 13 & 12 & 10 & 11 & 10 & 16 \\
\hline $\begin{array}{l}\text { Duration of } \\
\text { Observation } \\
\text { (min) }\end{array}$ & 45 & 43 & 45 & 75 & 20 & 45 & 36 & 80 & 90 & 45 & 100 & 70 & 30 & 100 & 100 \\
\hline $\begin{array}{l}\text { Duration of a } \\
\text { Session } \\
\text { (min) }\end{array}$ & 45 & $\begin{array}{l}43^{\star} 2 \\
(45)\end{array}$ & 45 & $\begin{array}{l}75^{\star} 2 \\
(90)\end{array}$ & $\begin{array}{l}80^{*} 2 \\
(90)\end{array}$ & 45 & $\begin{array}{l}60 * 2 \\
(75)\end{array}$ & $\begin{array}{l}80 * 3 \\
(90)\end{array}$ & 90 & 90 & 100 & $\begin{array}{l}70^{*} 4 \\
(100)\end{array}$ & 90 & 100 & 1 \\
\hline
\end{tabular}

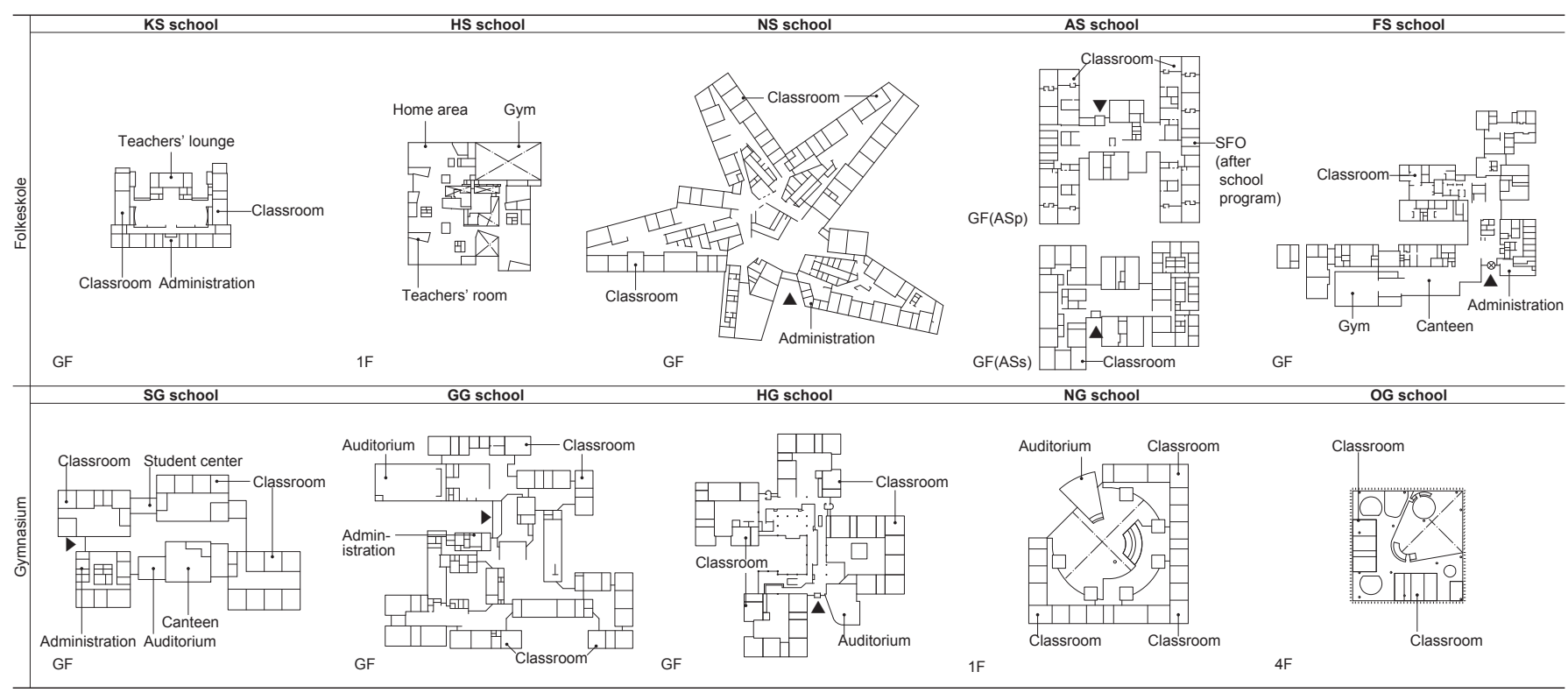

Fig.2 Plans of Sample Schools 
スコーレについて、KS 校はアウラと呼ばれる吹抜のホールを教室 で囲むアウラ・スコーレである ${ }^{16)}$ 。HS 校はオープンな空間で、パ ーティションで囲まれたスペースが学級の拠点となっている。NS 校は 3 つの学校の統合校で、星型の平面の中心にコモンコアと段 状の図書スペースがある。AS 校は 6 年生以下 (ASp) と 7 年生以上 (ASs) が別棟で、各棟に大階段のある共用空間がある。FS 校は、3 年生以上は教科教室のような運営方式を採用している。フォルケス コーレでは珍しい。分野毎に教室のクラスターがある。

ギムナジウムについて、SG 校はガラス屋根の空間に沿って、教 室等のクラスターや室が並んでいる。GG 校は平面的な広がりのあ る校舎である。 HG 校は校舎中心の吹抜の食堂に対し、教室のクラ スターが 4 方に接続している。NG 校は校舎の中心にコモンコアが あり、ガラス壁を介して教室のクラスターと視覚的に繋がってい る。OG 校は、オープンスペースが地下から 5 階まで、吹抜で連続 した一体空間となっている。教員が予めガラス壁に囲われた教室も しくはオープンな教室のどちらかを予約し、生徒は授業の場所を Web システムで確認する。いずれも公立で授業料は無料である注5)。

\section{2-3. 調査の方法}

校舎の図面、延床面積等の建築概要、児童生徒数等の学校概要を、 建築専門誌、設計事務所、学校等から収集し、Webページで情報を 補足した（Table 2)。訪問調査により、英語の授業で使われる空間 と物的要素の現況確認、英語の授業を担当している教員注 6 ) との面 談、英語の授業における児童生徒と教員の行動観察を行った。面談 調查の内容は主に、英語の教育内容、教材、英語の授業活動で使用 している場所等である。行動観察調查は、英語の授業の内容、児童 生徒と教員の活動、利用場所を、デジタルカメラとビデオカメラで 記録した。教室内の視野を広くとることができる地点から教室全体 を撮影した。また、授業の内容や、児童生徒や教員の活動に変化が 生じたと考えられる際に、教室内外の览童生徒と教員がいる場所に 近付いて、部分を撮影した。面談調查は 10 校、行動観察調查は学校 の許可が得られた 9 校 15 の授業で実施した。観察した授業の概要を 示寸 (Table 3)。授業時間については、フォルケスコーレは 45 分か ら 90 分まで様々である。ギムナジウムは $90 \sim 100$ 分が多く、間に 5 ～10 分程度の休㮃を挟むこともある。

\section{3. 英語の授業内容と利用している場所の概況}

英語の授業内容と、関連する教育、授業と準備に使用している場 所について、年間を通じた概況を把握するため、英語を担当してい る教員にヒアリングを行った。メールでの教員への質問、訪問時の 授業観察、カリキュラムによって情報を補足している。

\section{3-1. 英語教育と科目横断的な授業及び課題に関するヒアリング}

デンマークでは、英語はフォルケスコーレ 1 年生から必修である が、0 年生から始める学校もある (Table $4[\mathrm{Q} 1])$ 。ギムナジウムでは、 3 年間の $\mathrm{A}$ レベルもしくは 2 年間の B レベルを履修する。英語の授 業を担当する教員の人数は 1 クラス 1 名であるが、フォルケスコー レでは、学年、授業内容、児童生徒の性質等により、もう1名、教 員やペダゴー注7) と呼ばれる職員が加わる場合もある [Q2]。

フォルケスコーレでは、教員はスピーキングを重視している [Q3]。4 技能全て重要であるが、と前置きした上で、デンマークで は口述を最優先することが、長い間続いてきた伝統であるという。
ギムナジウムでは、授業を英語で行うこと、生徒が主体的に取り組 むこと等を教員は心がけている。文章を読むことは家で 1 人でもで きるので、授業では生徒が英語を話し、協働する時間が重要だとい う意見もあった。授業の内容は、フォルケスコーレでは、会話やデ イスカッション、文法、プレゼンテーション注8) に加え、文章や詩 の読解、ゲーム、歌等が行われている $[Q 4]$ 。複数の教員からテス 卜はあまりやらないといら話があった。形成的評価、個別相談等が なされている。ギムナジウムでは、会話やディスカッション、文 法、文章や詩の読解、プレゼンテーション、エッセイに加え、映像 課題等が行われている。エッセイはフォルケスコーレよりもギムナ ジウムで取り組んでいる。全国統一の修了試験があり、英語は、長 文を分析し 1000words 程度注9) のエッセイで回答する 5 時間の筆記 試験と口述試験から成る。教材は、フォルケスコーレでは、教科 書や文法のワークブック、動画や映画、本、電子黒板ゲームの他、 本、プリント、デジタル教材等を使用している [Q5]。児童生徒本 人が望むことに取り組み、自主性を高めるように、複数の教材を常 に用意している教員もいた。ギムナジウムでは、電子書籍やオンラ インの課題等、デジタルの教材をより多く使うようになっている注 10)。全国共通のオンラインプラットフォームが導入されている。GW やPW は全ての対象校でなされており [Q6]、児童生徒の関与を高め、 協㗢する力を育んでいる。GW なしの授業は 1 度もしたことがない 教員もいた ${ }^{\text {i } 11)}$ 。授業で扱う題材は、教員や児童生徒に裁量がある 注 12) 21 22) $[Q 7]$ 。ギムナジウムでは、英語圈の国の歴史や文化に加え、 生徒のコースや関心に応じた題材も扱う。

プロジェクト授業は、フォルケスコーレでは、 1 学期に 1 回程度 から全体の $50 \%$ 程度と、頻度に差がある [Q8]。低学年はペアで小 さな課題、高学年はプロジェクト授業に移行するといった配慮があ る。ギムナジウムでは、他教科とジョイント授業を行ったり、ト

Table4 Interview to English teachers about English education and transversal competences

\begin{tabular}{|c|c|c|c|c|c|c|c|c|}
\hline No. & Question & Answer & $\mathrm{F}$ & 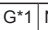 & Question & Answer & $\mathrm{F}$ & $\bar{G}$ \\
\hline \multirow{2}{*}{ Q1 } & \multirow{2}{*}{ Start grade } & 0 & 3 & - & \multirow{4}{*}{$\begin{array}{l}\text { Group work } \\
\text { or pair work }\end{array}$} & Almost every lesson & 3 & 5 \\
\hline & & 1 & 2 & 5 & & Every week & 2 & 0 \\
\hline \multirow[b]{2}{*}{ Q2 } & \multirow{2}{*}{$\begin{array}{l}\text { Number of } \\
\text { teachers }\end{array}$} & 1 & 1 & 5 & & Every month & 0 & 0 \\
\hline & & partly with an extra & 4 & 0 & & Other & 0 & 0 \\
\hline \multirow{5}{*}{ Q3 ${ }^{\prime}$} & \multirow{5}{*}{$\begin{array}{l}\text { Most important } \\
\text { consideration }\end{array}$} & Speaking & 5 & $3 * 2$ & \multirow{7}{*}{ Topic } & $\begin{array}{l}\text { History or culture of } \\
\text { English speaking country }\end{array}$ & 4 & 5 \\
\hline & & Listening & 1 & 0 & & Students' interest or & 3 & \\
\hline & & Reading & 1 & 0 & & & & \\
\hline & & Writing & 2 & 0 & & National curriculum & 3 & 3 \\
\hline & & Other & $2 * 3$ & $3 * 4$ & & Local curriculum & 0 & 0 \\
\hline \multirow{5}{*}{ Q4 } & \multirow{5}{*}{ Contents } & Conversation, discussion & 5 & 5 & & School curriculum & 12 & $\frac{2 * 10}{2}$ \\
\hline & & Grammar & 5 & 5 & & Other & & $\overline{2^{*} 12}$ \\
\hline & & Test & 5 & 5 & \multirow{5}{*}{ Project } & Every week & 1 & 0 \\
\hline & & Presentation & 5 & 5 & & Once a month & 0 & 3 \\
\hline & & Other & $5 \star 5$ & $5^{*} 6$ & & Once a semester & 1 & 2 \\
\hline \multirow{8}{*}{ Q5 } & \multirow{8}{*}{$\begin{array}{l}\text { Teaching } \\
\text { material }\end{array}$} & Textbook & 4 & 4 & & Once a year & 0 & 0 \\
\hline & & Workbook & 5 & 2 & & Other & $3 * 13$ & 0 \\
\hline & & Print & 3 & 3 & \multirow{3}{*}{$\begin{array}{l}\text { Q9 } \begin{array}{c}\text { with another } \\
\text { subject teacher }\end{array}\end{array}$} & Joint lessons & 2 & 5 \\
\hline & & Pdf files & 2 & 5 & & Discussion about topics & 2 & 2 \\
\hline & & Book & 5 & 5 & & No & 2 & 0 \\
\hline & & $\begin{array}{l}\text { Interactive whiteboard } \\
\text { game or tablet game }\end{array}$ & 4 & 1 & \multirow{3}{*}{ Q10 Big assignment } & Final year & 5 & 5 \\
\hline & & Video*7 & 5 & 5 & & Another year & 2 & 5 \\
\hline & & Other & & $4^{*} 9$ & & Other & $1 * 14$ & 0 \\
\hline \multicolumn{9}{|c|}{ 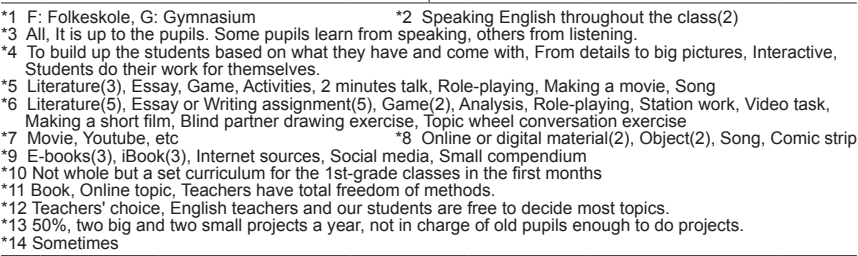 } \\
\hline
\end{tabular}


ピックのタイミングを合わせて、科目横断的な能力を育んでいる [Q9]。フォルケスコーレ、ギムナジウムともに最終学年では、学際

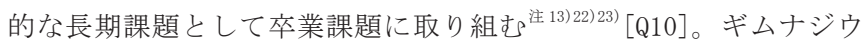
ムでは、原則 2 科目を選択し、教員の指導を受けて執筆する。その うち 1 科目に英語を選択することも多い。

\section{3-2. 英語の授業と準備の主な場所に関するヒアリング}

英語授業の主な場所は、フォルケスコーレでは、4 校が学級の普 通教室等である (Table 5 [Q1])。残りの 1 校は、3 年生以上は教科教 室のような運営方式であり、英語や語学専用の教室がある。ギムナ ジウムの対象校では、2 校が学級毎の普通教室を使用している ${ }^{\text {注 } 14)}$ 残りの 3 校には学級毎の教室はない。うち 2 校は特定の学級や科目 の専用ではない教室 (以下一般教室) を使用し、1 校は語学教室と 一般教室を併用している。

教員の授業準備の場所は、フォルケスコーレの対象校には、英語 や語学専用の教員室はなく、学年毎の教員室等が使用されている [Q2]。ギムナジウムは 4 校に語学もしくは英語の教員室があり、分 野の近い教員と同室であると日常的に相談できるのでとてもよい、 と評価されている。教材庫は、フォルケスコーレでは 1 校に語学の 教材庫が、ギムナジウムでは 3 校に英語の教材庫が設けられている [Q3]。一方で複数の教員から、近年はデジタルやオンラインの教材 をより多く使っているので、教材庫は以前ほど必要ではない、とい う指摘があった。教材庫よりも図書室の司書による資料収集の支援 サービスが重宝している、という意見もあった。

現状の施設や設備に対する要望として、フォルケスコーレの英語 教員からは、グループルームや会議室等の小室の増強、英語教室の 設置、英語図書室の拡張、リスニングとスピーキングを学ぶ機器 注 15) の増強等が挙げられた [Q4]。ギムナジウムは、4 校で施設に満 足しており、他に要望するものはないという回答であった。満足し ている理由として、コモンスペース等の生徒が学ぶ空間が物理的に 多くあること、授業を行う空間の大きさや種類が豊富であること等 が挙げられた。残りの 1 校で、教室が狭い、他の学校のように全教 員が集まることができる教員ラウンジがほしい、という要望があっ た。現状の校舎は英語の授業に良いもしくは悪い影響があるか尋ね
たところ、フォルケスコーレ 4 校、ギムナジウム 3 校において、良 い影響があるという回答があった $[\mathrm{Q} 5]$ 。良い影響がある理由とし て、フォルケスコーレでは、オープンスペースがあることで机や椅 子を動かさずに様々な学習スタイルに対応でき、児童生徒が同時に 別々のことに取り組み、力を発揮できる環境を多様な家具や空間か ら選択できることが挙げられた。ギムナジウムではコモンスペース が十分にあるので頻繁に GW ができることや、生徒が英語を話しや すいことが挙げられた。大きな吹抜のコモンコアがあるギムナジウ ムの校舎では、GW 等の際に生徒の場所がわかりやすいといった視 認性の良さや、生徒の自立性や集中寸る力を高めることが評価され た。一方で、開放的な空間が苦手な生徒もおり、影響は生徒によっ て異なることも指摘された。

\section{3-3. 英語の授業活動が行われる場所と範囲に関するヒアリング}

授業の活動は、1つの教室の中で行われることもあれば、広く分 散したセッティングのシステムの中で行われることもある。本節で は英語の授業活動がどこまで及んでいるのか、その範囲を把握す る。英語の授業で使用している場所について教員にヒアリングを行 い、前述のラポポートによるセッティングのシステムを参考に図を 作成した (Fig. 3)。

フォルケスコーレでは、教室、教室近くのコモンスペース、グル

Table5 Interview to English teachers about space and facilities

\begin{tabular}{|c|c|c|c|c|}
\hline No. & Question & Answer & $\mathrm{F}$ & $\mathrm{G}^{* 1}$ \\
\hline \multirow{4}{*}{ Q1 } & \multirow{4}{*}{ Main space for English lessons } & English room & 1 & 0 \\
\hline & & Language room & 1 & 1 \\
\hline & & Students' classroom or class space & 4 & 2 \\
\hline & & Unattached classroom or space & 0 & 3 \\
\hline \multirow{3}{*}{ Q2 } & \multirow{3}{*}{ English or language teachers' room } & English teachers' room & 0 & 1 \\
\hline & & Language teachers' room & 0 & 3 \\
\hline & & No & 5 & 1 \\
\hline \multirow{3}{*}{ Q3 } & \multirow{3}{*}{ English or language storage } & English storage & 0 & 3 \\
\hline & & Language storage & 1 & 0 \\
\hline & & No & 4 & 2 \\
\hline \multirow{3}{*}{ Q4 } & \multirow{3}{*}{ Do you need anything more about facilities? } & No. I am content with them. & 2 & 4 \\
\hline & & Yes. (about facilities) & $4^{*} 2$ & $1 * 3$ \\
\hline & & Other & $1^{*} 4$ & $1 * 5$ \\
\hline \multirow{3}{*}{ Q5 } & \multirow{3}{*}{$\begin{array}{l}\text { Does school building have a good or bad effect } \\
\text { on English lessons? }\end{array}$} & Good & 4 & 3 \\
\hline & & It depends on the students. & 0 & 2 \\
\hline & & Other & $1 * 6$ & 0 \\
\hline & $\begin{array}{l}\text { Folkeskole, G:Gymnasium } \\
\text { ore group or small room }(2) \text {, English room, Bigger } \\
\text { eaking practice; headphones, and online portals } \\
\text { gger classrooms, One room where all teachers c } \\
\text { gre times to prepare lessons } * 5 \text { More licenses of }\end{array}$ & $\begin{array}{l}\text { in library, Glass walls, More for lister } \\
\text { students speak and get feedback } \\
\text { et, hang out, relax, and talk to collea } \\
\mathrm{s} \star 6 \text { It does not really help much. }\end{array}$ & & \\
\hline
\end{tabular}
$* 3$ Bigger classrooms, One room where all teachers can meet, hang out, relax, and talk to colleagues
$* 4$ More times to prepare lessons * 5 More licenses of eBooks * 6 It does not really help much.

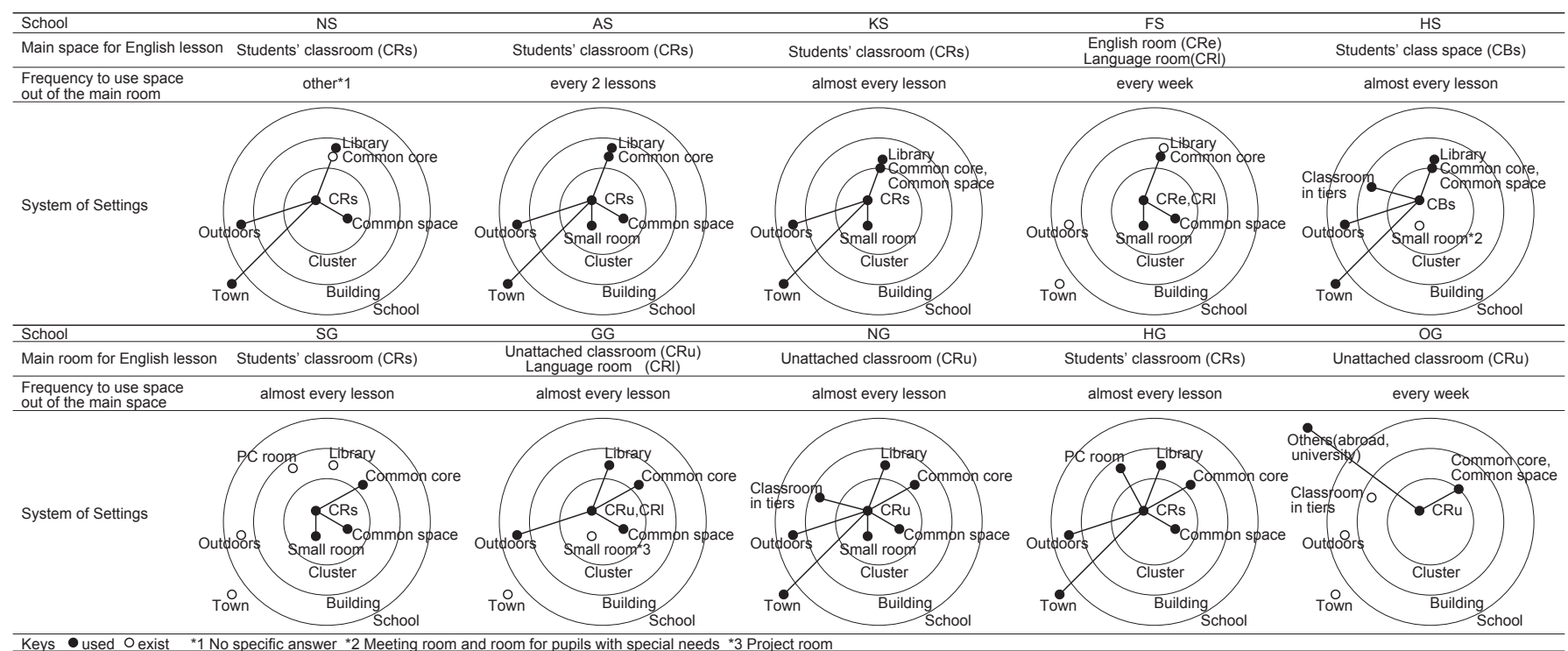

Keys • used O exist * 1 No specific answer *2 Meeting room and room for pupils with special needs *3 Project roo 
ープルーム、コモンコア、図書室等が使用されている。更に敷地内 の屋外空間、映画館や劇場、美術館や博物館等、授業の活動は学校 の外にも広がっており、社会や生活に接続して英語を実践すること が意図されている。校外は教職員 2 名で引率する。図書室は積極的 に 1 週間に 1 回程度使用している教員もいれば、本より PCをより 頻繁に使う教員もいる。PCで読み続けると子どもが退屈するので、 時々図書室に本をとりに行かせるという回答もあった。

ギムナジウムでは教室に加えてコモンスペース、コモンコアとい った校舎内のオープンスペースが、対象校全てにおいて使用されて いる。図書室は、生徒が学際的な課題に取り組む際や、教員が授業 準備の際に使用寸るが、英語の授業で使用寸る頻度は高くない。他 に、NG 校の教員は詩の発表等で階段教室を使用し、OG 校では大学 への訪問やイギリス等の海外への学習旅行もなされている。フォル ケスコーレ、ギムナジウムともに、小室については授業用ではない ものを除いて、設置されている校舎ではどの教員も授業で使用して いると回答している。

\section{4. 英語の授業内容と利用している場所、空間と物的要素の実態}

具体的にどのように英語の授業が行われているのか、詳細を把握 するため 15 の授業について観察した。授業の内容とその展開、教材、 教室廻りの空間構成、使用した場所、物的要素、児童生徒の位置に ついて調査した。

\section{4-1. 英語の授業内容の展開、使用教材に関する観察結果}

授業展開をFig. 4 に、使用された教材をTable 6 に示す。観察し た英語の授業を、複数の課題に取り組むものと、1つの課題にじっ くり取り組むものに大別した。前者は主に文学を扱うもの、プレゼ ンテーションと動画を扱うもの、1つの題材について様々な内容を 盛り込むものである。後者は文法、エッセイ、小プロジェクトを扱
うものが観察された。英語を学ぶだけではなく、プレゼンテーショ ン、エッセイ、Web ページ作成等のように、英語を使って何かをす る授業が観察された。言語の使用者と学習者を社会的に行動する 者・社会的存在と見なし、行動の遂行を可能にする一般能力とコミ ユニケーション言語能力を育む、行動中心主義注 16)24) が実践されて いると考えられる。教員の説明時間はさほど長くなく、まとまった 時間を児童生徒が課題に取り組むことに充てている。その間、教員 は巡回して質問や相談を受ける。GW や PW が多くの授業でなされ、 協働して問題を解決する力を育むことが重視されている。児童生徒 が英語を聞き、話す時間が確保され、ギムナジウムでは授業全体が 英語で行われることも珍しくない。全国共通のオンラインプラット フォームはフォルケスコーレ、ギムナジウム共に導入されている が、特にギムナジウムで頻繁に使われている様子が観察された。例 えば、授業の前に個々のノートPC から長文の PDF 等の教材を受け 取り、予め読んでおき、授業では GW で分析しながら課題の word つ アイルに書き込み、授業後にアップロードして提出している。

Table6 Teaching materials used in observed English lessons

\begin{tabular}{|c|c|c|c|c|c|c|c|c|c|c|c|c|c|c|c|c|}
\hline Lessons & & NS1 & NS2 & AS1 & AS2 & AS3 & FS1 & KS1 & SG1 & SG2 & SG3 & GG1 & $\mathrm{GG} 2$ & $\mathrm{HG} 1 \mathrm{~N}$ & NG1 & OG1 \\
\hline Grade*1 & & F5th & F5th & F3rd & F6th & F7th & F6th & F9th & G1st & G1st C & G2nd & G1st & G2nd & G1st & G1st & G2nd \\
\hline \multirow{8}{*}{$\begin{array}{l}\text { Teaching } \\
\text { materials }\end{array}$} & Textbook & $\mathrm{v}$ & & $v$ & & & & & & & & & & & & \\
\hline & Workbook & & & & & & & & $\checkmark$ & $\checkmark$ & & & & & & \\
\hline & Data file & & & & & & & & $\checkmark$ & $\checkmark$ & $\begin{array}{l} \\
\end{array}$ & $v$ & $\checkmark$ & & $\checkmark$ & \\
\hline & Print & $\mathrm{v}$ & $\mathrm{v}$ & & $\mathrm{v}$ & $\begin{array}{lll} \\
v\end{array}$ & & & & 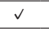 & $\mathrm{v}$ & $\begin{array}{lll} & & \\
\end{array}$ & $\checkmark$ & & $v$ & \\
\hline & Book & & $\checkmark$ & & & & & & $\checkmark$ & & & & & & & $\checkmark$ \\
\hline & Movie & & & & & & & & & & $\checkmark$ & $\checkmark$ & & $\checkmark$ & $\mathrm{v}$ & \\
\hline & $\begin{array}{l}\text { Online } \\
\text { assignment }\end{array}$ & & & & & & & $\checkmark$ & & & & & & & & \\
\hline & Item & & & $\checkmark$ & & & & & & & & & & & & \\
\hline \multirow{3}{*}{$\begin{array}{l}\text { Writing tools } \\
\text { of students' }\end{array}$} & S Notebook & & & & & & & & $\checkmark$ & & & & & & $v$ & \\
\hline & Laptop & $\checkmark$ & $\checkmark$ & & $\mathrm{v}$ & $\mathrm{v}$ & $\checkmark$ & $\checkmark$ & $v$ & $\checkmark$ & $\mathrm{v}$ & $\checkmark$ & $\checkmark$ & $\checkmark$ & $\checkmark$ & $\checkmark$ \\
\hline & Audio & $\checkmark$ & & $\checkmark$ & & & & & & & & & & & & \\
\hline \multirow{4}{*}{$\begin{array}{l}\text { Supporting } \\
\text { materials }\end{array}$} & Post-it & & & & & & & & & & $\checkmark$ & & & & & \\
\hline & Ball & & & & & & & & & & & $\checkmark$ & & & & \\
\hline & Card & & & $v$ & & $\mathrm{v}$ & & & & & & $\begin{array}{l} \\
v\end{array}$ & & & & \\
\hline & Catalog & & & $\checkmark$ & & & & & & & & & & & & \\
\hline
\end{tabular}

1 F:Folkeskole, G:Gymnasium

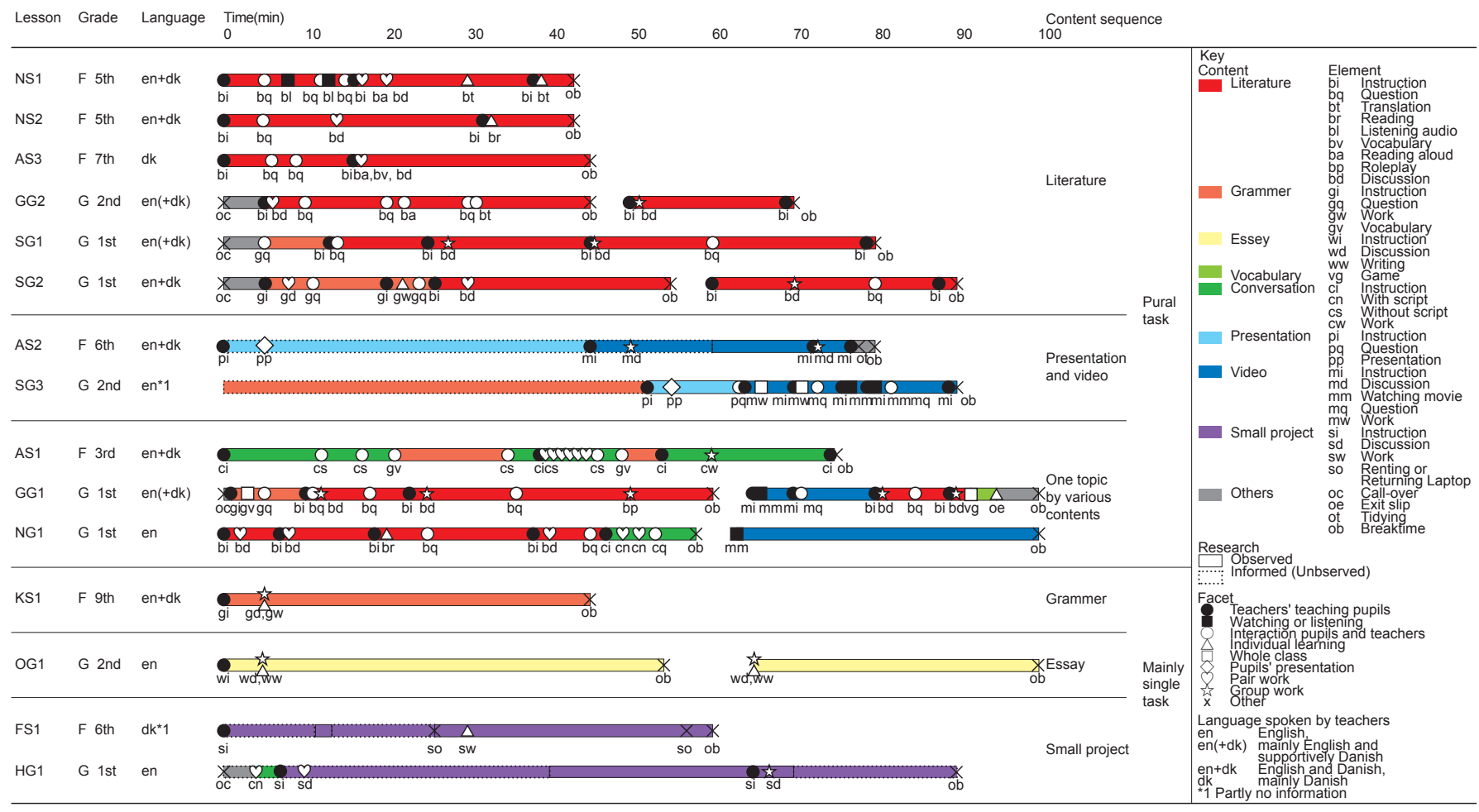

Fig.4 Content sequence of observed English lessons 


\section{4-2. 英語授業の中心的なスペースとその廻りの空間構成}

観察した授業において、開始時に教員と児童生徒が集まる授業の 中心的なスペースは、概ね教室であった。OG1 はコモンコアのオー プンな教室で授業が行われた。中心的なスペースの座席のレイアウ 卜を、線状 (Line)、馬蹄形 (Horseshoe)、島型 (Island)、線状と島 型の混合 (Line and 1sland) に整理した (Fig. 5)。フォルケスコー レは島型が 4 つ、線状と島型の混合が 2 つ、馬蹄形が 1 つの授業で 観察された。ギムナジウムは線状が 1 つ、馬蹄形が 5 つ、島型が 2 つの授業で見られた。英語教室と語学教室は島型である。中心的な スペース以外のコモンコア、コモンスペース、グループルームにつ いては、机のレイアウトは、概ね島型である。

授業の中心的なスペースの迴りには、様々な学習形態や集団編成 に対応し、個々に特性が異なる児童生徒を支えるため、広がりのあ る空間や、室や家具によってスケールダウンした環境が見られる。 共用空間等の教室より大きな空間と、教室より小さい空間及びスケ ールダウンする家具から、空間の構成を検討する（Fig. 6)。

教室より大きな空間について、通行を目的とした細い廊下のみに 教室が接している事例は見当たらず、全事例でコモンスペースやコ モンコア等の広がりのある空間に接している注 17)。教室に接してい る共用空間の種類を、クラスターがなく教室がコモンコアに直接接 しているもの、クラスターがありコモンスペースが 1 層のもの、コ モンスペースが吹き抜けで 2 層のものに整理した。

教室より小さい空間とスケールダウンする家具について、グルー プルーム、アルコーブ、キャレル等の家具がみられた。フォルケス コーレでは、高学年棟のAS3 を除き、観察した全ての教室廻りにア ルコーブもしくはスケールダウンする家具があり、多様な巟童生徒 への対応がなされている。AS 校はコモンスペースにどの学年もグ ループルームを有する。教室内は 3 年生にアルコーブ、 6 年生にパ ーティション、7 年生はなし、と年次に応じた設えがなされている。 FS 校は主に 6 年生以下が利用する教室の中に、プロジェクター付 きの段状の小スペースが区切られており、説明と質問に特化した場 が設けられている。ギムナジウムは、グループルームがあるものが 4つ、ないものは 4 つであった。

\section{4-3. 使用場所、物的要素と児童生徒の位置に関する観察結果}

観察調查によって、英語の授業で使用された場所、物的要素と児 童生徒の位置を確認した。使用された場所は、教室、教室付近のコ モンスペース、別の階のコモンスペース、グループルーム、教材庫、 コモンコア、別の階のコモンコア、コモンコア内のグループルーム、 別のクラスター内のコモンスペースである（Fig. 7)。1つの授業を 通じた使用場所の展開を検討すると、フォルケスコーレでは、2 事 例で教室内のみ、 5 事例で教室外の空間に 1 回出ていた (Fig. 8)。 ギムナジウムの授業の使用場所の展開は様々であり、3 事例で教室 内のみ、1 事例でコモンスペースのみ、 1 事例で教室外の空間に 1 回出ており、3 事例で 2 回出ている。それぞれの場所における物的 要素と児童生徒の位置の種類を Table 7 に示す。

\section{5. 英語の授業活動とセッティングのシステム}

英語授業の行動観察調査の結果から、児童生徒の活動パスを作 成し、4-1 で捉えた授業展開と 4-3 で把握した使用場所の展開の関 係から整理した (Fig. 9)。複数の課題に取り組む授業のうち、主に
文学を扱う授業では、教室に加えて教室外の空間に 1 回出る NS1, NS2, AS3, GG2 と、2 回出る SG1, SG2 がある。いずれの授業も、教室 内で一斉授業に比較的近い内容を行った後に、20 分以上のまとま った時間を $\mathrm{PW}$ や GW に充てており、児童生徒は教室内外の好きな空 間や家具に移動してディスカッションをしている。教室外の空間を 使う理由としては、環境を変えるため、必要に応じて教員が児童生

\begin{tabular}{|c|c|c|c|}
\hline Line & Horseshoe & Island & Line and Island \\
\hline 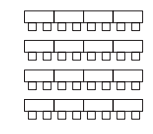 & 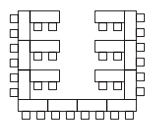 & 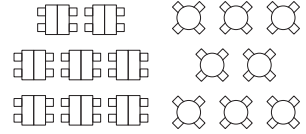 & 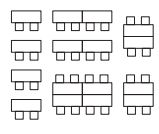 \\
\hline $\begin{array}{lc}\text { F } & 0 * 1 \\
\text { G } & 1 \text { (CRu1) } \\
* \text { *1 Number of } m \\
\text { CRu: Unattache }\end{array}$ & $\begin{array}{c}\text { 1(CRs1) } \\
\text { 5(CRs4,CRu1) } \\
\text { s F:Folkeskols } \\
\text { om, CRe: Englist }\end{array}$ & $\begin{array}{c}\text { 4(CRss,CRe1) } \\
\text { 2(CRI1, CC1) } \\
\text { m, CRs:Students' clas } \\
\text { nguage room, CC:Co }\end{array}$ & $\begin{array}{c}2 \text { 2(CRs2) } \\
0\end{array}$ \\
\hline
\end{tabular}

Fig.5 Seat layout of the main space in observed English lessons
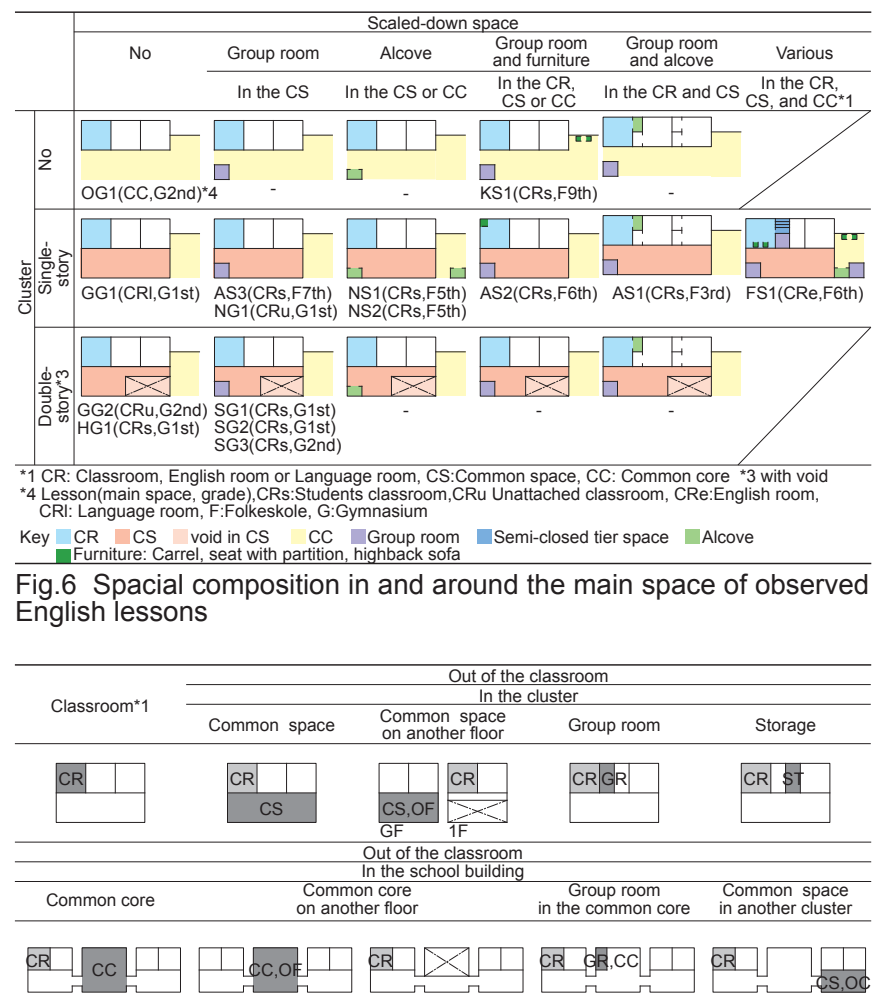

Key $\square$ Space $\square$ Main space * *1 including English room and language room

Fig.7 Space used in observed English lessons

\begin{tabular}{|c|c|c|c|c|}
\hline \multirow{2}{*}{ Space } & \multicolumn{4}{|c|}{ Space sequence } \\
\hline & $\mathrm{CR}^{* 1}$ & out of $C R$ & CR + out of CR once & CR + out of CR twice \\
\hline $\begin{array}{l}\text { Classroom }{ }^{\star} 2 \\
\text { Common space } \\
\text { Common space, OF } \\
\text { Group room } \\
\text { Storage }\end{array}$ & & & & $\Rightarrow \square$ \\
\hline $\begin{array}{l}\text { Common core } \\
\text { Common core, OF } \\
\text { Group room, CC } \\
\text { Common space, OC }\end{array}$ & & & & \\
\hline Number of Lessons & $F 2, G 3^{* 3}$ & $\mathrm{Fo}, \mathrm{G} 1$ & & FO, G3 \\
\hline
\end{tabular}

Fig.8 Students' space sequence of observed English lessons

Table7 Student position and environmental element in observed English lessons

\begin{tabular}{|c|c|c|}
\hline Space & Student posture & Student position and environmental element \\
\hline \multirow{3}{*}{ Main room or space } & Seated & $\begin{array}{l}\text { Seat, Another seat, Carrel, Seat with partition, Bench, Window sill, } \\
\text { Tiers }\end{array}$ \\
\hline & Seated on the floor & Floor, Carpet \\
\hline & Standing & $\begin{array}{l}\text { Vacant space, Drawing board rail, Whiteboard, Blackboard, } \\
\text { Students' shelf }\end{array}$ \\
\hline \multirow{3}{*}{$\begin{array}{l}\text { Other spaces used in } \\
\text { English lessons }\end{array}$} & Seated & $\begin{array}{l}\text { Table with chair, High table with chair, Table with sofa, } \\
\text { Table with sofa and chair, Table with highback sofa, } \\
\text { Alcove, Bench, Sofa, Tiers }\end{array}$ \\
\hline & Seated on the floor & Floor, Carpet \\
\hline & Standing & Vacant space, Drawing board rail, Copy \\
\hline
\end{tabular}




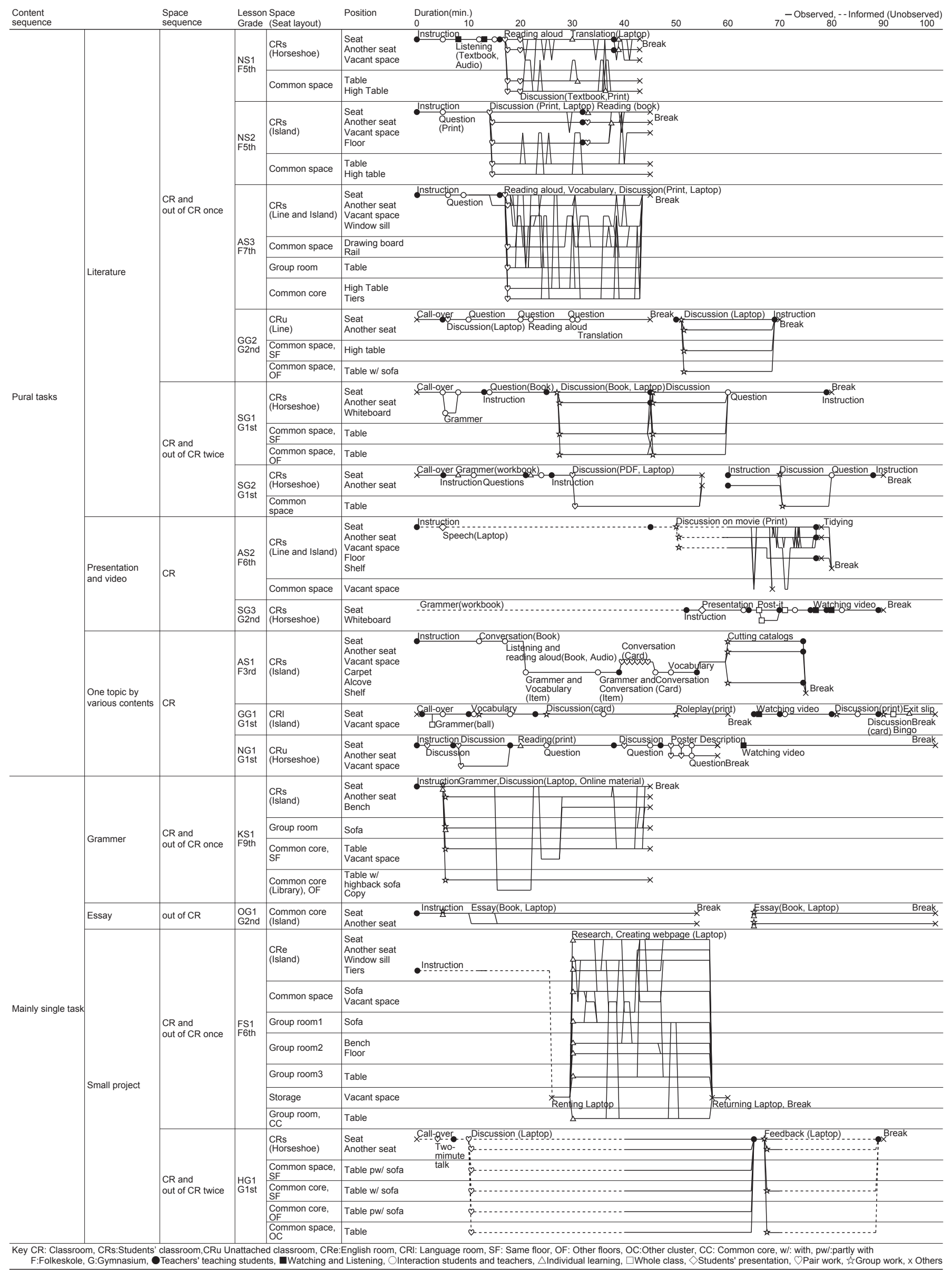

Fig.9 Activities and systems of settings in observed English lessons 
徒をより良く助けるため、英語を話すにはスペースが必要等が、教 員から挙げられた。教室の外に 2 回出る事例では、GW のメンバー を組み替えている。GW では積極的に話す人とそうでない人に分か れてしまう可能性があるので、最初のグループの議論を、次のグル ープのメンバーに伝えさせることで、学級の全員が活動的である状 態にしている。

映画等の動画と児童生徒のプレゼンテーションを扱う AS2, SG3 は プロジェクターを使用し、概ね教室で行われている。 SG3 はホワイ トボードに付箋紙を貼る等、教室内で生徒を動かしている。

AS1, GG1, NG1 は $1 つ の$ 題材について様々な内容を盛り込んだ授業 であり、いずれも教室内で行われている。AS1 は買い物を題材とし たフォルケスコーレ 3 年生の授業である。席で説明を聞き、音読し、 カーペットに集まり実物の商品を見ながら語彙や文法を学び、教室 内で散らばりペアを組み換えながら会話の練習をし、カタログを切 り取りグループで店をつくる。授業の要素を切り替え、児童の姿勢 や位置も動かしている。ギムナジウムの GG1, NG1 は授業の序盤で生 徒をまず立位で動かし、その後もこまめに授業の内容や要素を切り 替えて、生徒を飽きさせない工夫がされている。

$1 つ$ 課題にじっくり取り組む授業のうち、文法のオンライン課 題を解く KS1 は、教室、グループルーム、コモンコアとコモンスペ ースが一体になった空間で、他の階を含めて様々な場所に生徒が分 散している。教室外の空間を使う理由は、子どもたちが望むから、 下級生は教室の中で教員に強制されるのではなく、共用空間で自立 して学ぶ上級生に憧れがある、とのことだった。教員も児童生徒の 自立を重視しており、彼らが自分の集中できる空間を理解し、選択 することを、徐々に習得するようにサポートしている。OG1 は最初 から最後までコモンコアの開放的な空間でエッセイを書く。OG 校 は教室やオープンスペースを、教員が事前に予約しておくシステム であり、教室と教室外の空間の両方を 1 つの授業で使うことはあま りなく、授業の内容に応じてどちらかを選択することが多い。OG1 の教員は、教室外の空間を使うのは教員が生徒に近づいて課題を助 けるためであり、伝統的な教室はそれには適していないと感じて いる。FS1, HG1 は小プロジェクトである。FS1 は教室内の段状のス ペースで説明を受けた後、教材庫でPC を受け取り、教室の空辺や コモンスペースのソファー、グループルーム等に散らばり、様々な 姿勢でオーストラリアの動物の英語の Web ページを作成している。 教室外の場所を使用寸る理由は、集中寸るためとのことであった。 HG1 は近くの席の生徒と英語で日常会話をし、説明を受けた後、コ モンスペースやコモンコアに散らばり、前回の授業で撮影した英語 のインタビュー動画についてディスカッションし、一旦教室に戻っ た後、再度分散して別のペアと動画を見せあい、フィードバックを 受けている。教員によると、こうした授業は一つの部屋では困難で、 生徒は教室の外で静かな場所を見つけることを認められている、彼 らは人の目を気にしなくてよい状態を必要としている、とのことで あった。

机のレイアウトに着目すると、教室内で完結している授業は、動 画を視聴する 2 事例は馬蹄形だが、残りの 3 事例は島型もしくは線 状と島型の混合である。その他の授業では、教室外のスペース、つ まり概㸚島型のレイアウトのスペースも使用している。従って、観 察した英語の授業では、動画視聴の 2 事例を除き全ての事例で、島
型のレイアウトを、授業を通じてもしくは部分的に使用している。 デンマークにおいても 20 ～ 30 年程前は、文法訳読法の授業がな されていた。ギムナジウムで、英語の授業内容や場所について、様々 な工夫がなされるようになったのは、授業時間が 45 分から 90 〜 100 分程度に長くなったことが決定的だった、文を読むだけでは持 たないので、生徒が飽きないように工夫する必要が生じた、と教員 から補足があった。

\section{6. まとめ}

デンマークのフォルケスコーレ 5 校とギムナジウム 5 校の計 10 校、15 の英語授業について、授業内容、利用している場所、授業 活動とセッティングのシステムを検討し、以下の結論を得た。

3 章、英語の授業内容と利用している場所の概況について、フォ ルケスコーレでは、スピーキングが重視されている。英語の授業活 動は、屋外空間や学校外の博物館等にも広がり、社会や生活に接続 した教育が実践されている。ギムナジウムでは、スピーキングや生 徒が主体的に取り組むこと等が重視されている。空間の大きさの種 類の豊富さや、生徒が学ぶコモンスペースが多くあることが、教員 の施設に対する満足感に繋がっている。語学の教員室を設けている 学校もあり、分野の近い教員と同室であることで支え合いが促進さ れ、教員から好評であった。

4 章、英語の授業内容と利用している場所の実態及び空間と物的 要素について、英語を学ぶだけではなく、英語を使ってを何かをす る授業が観察され、行動中心主義が実践されている。児童生徒が英 語を聞き、話し、課題に取り組むことに、まとまった時間が充てら れている。GW や PW が多くの授業でなされ、協働する力が育まれて いる。英語の授業の中心的なスペースとその廻りの空間構成、机の レイアウト、使用場所、物的要素を把握した。

5 章、英語授業の活動とセッティングのシステムについて、文学 や1つの課題に取り組む授業では、教室内外の様々な場所に散らば ることで、人の目を気にせず英語を話したり、ディスカッションし やすい状態がつくられている。1つのトピックについて多くの内容 や要素を扱う授業、動画、プレゼンテーションは、教室内で完結す るものが多いが、児童生徒を教室内でまず動かしたり、内容をこま めに切り替え、児童生徒を飽きさせない工夫がされている。机のレ イアウトは、動画視聴の 2 事例を除いた全ての授業で、授業を通じ てもしくは部分的に、島型のレイアウトが使用された。

日本の学校の英語教育では、意欲的に多様な授業に取り組む教員 がいる一方で、特に中学校と高等学校では文法訳読法を中心とした 一斉授業も根強い。デンマークの学校における英語を「話す」こと を重視し、協働的で実践的な授業は、今後の日本の英語教育にも参 考になると考えられる。日本の学校において、英語の授業で 4 技能 をバランスよく育成するためには、坚童生徒が「話す」ためのセッ ティングが必要である。教室内外の少なくとも一方で、机のレイア ウトが島型であるスペースが利用できること、児童生徒が距離を取 ることができる物理的に広い空間があることが望ましい。本稿で調 査したデンマークの各授業の活動とセッティングのシステムについ ても、日本の学校や教員、建築計画者、設計者に示唆を与えるもの と考えられるが、国や自治体が施策や指針を作成する上では、日本 の学校とデンマークの学校では、教員が置かれている状況が異なる 
ことに注意したい。デンマークの教員も非常に多忙であるが、日本 の公立学校の教員と比較すると、教育や授業準備に集中しやすい体 制が整えられている。児童生徒の学校生活を支える役割は、担任教 員ではなく、フォルケスコーレではペダゴー、ギムナジウムではカ ウンセラーといったように、主に専門の職員が担っている。部活動 に多大な時間を割くことはない。図書室の司書や ICT オフィスのス タッフも、日常的に教員の授業準備や児童生徒の学習の助けとなっ ている。ICT を活用するためのオンラインプラットフォームは、全 国共通で整備されており、ICT に強い特定の教員に整備や管理運営 の負担が偏る心配はない。観察したデンマークの英語の授業の中 で、教室内で完結するものに関しては、教員の多くの準備の上に成 立していた。日本において同様の授業を実現するためには、教員の 負担や雑務の軽減、専門職員の配備が前提条件となる。他方、文学 を扱う授業のように、前半は教室内で一斉授業に比較的近い内容 で、後半は教室外にも広がり $\mathrm{GW}$ という展開は、授業準備の負担が 比較的少なく、文法訳読法の授業を行ってきた教員にも取り組みや すいと推測される。授業の後半において GW を十分に行うためには、 児童生徒が教室内外のスペースに広がって、距離を取ることができ る施設計画が重要である。

授業において、社会や生活に接続したかたちで英語を実践するた めには、屋外空間や地域の既存の施設を活用することも有効であ る。日本の小学校において日常的に校外に出るには、児童と教職員 の比率の改善が必要である。行動中心主義の英語教育については、 近年日本の公立小中学校においても 1 人 1 台端末が確保されたため、 英語でWeb ページを作成する授業等に対する設備上の準備は整いつ つある。こうした新しい教育をより多くの教員が実践するには、教 員ラウンジや、高等学校では語学の教員室等、教員が互いに支え合 うための空間の拡充が重要である。

本稿では、英語の授業活動とセッティングのシステムについて検 討したが、今後、他教科についても詳細な分析と検証が必要である。 本稿の知見のうち、英語を「話す」ためのセッティングや行動中心 主義の実践については、語学特有の内容であるので、他教科におい ては当てはまるとは限らない。他方、英語の文学の授業のように、 前半は教室内で一斉授業に比較的近い内容で、後半は教室外にも広 がりグループでディスカッションという展開は、デンマークにおい ては他教科でもなされていた。日本においても「主体的・対話的で 深い学び」や協働する力を育む学習活動とセッティングのシステム として、他教科においても参考になる可能性がある。

本稿は文献 25、26 で発表したものの一部に、調查、分析を加え、 加筆、修正してまとめたものである。

\section{謝辞}

本研究は JSPS KAKENHI $19 K 15168$ の助成による研究成果の一部 です。調查、図面提供にご協力を賜りました各学校、設計事務 所 3XN、CEBRA aarhus、Arkitema Architects、ERIK arkitekter、 Henning Larsen Architects、JJW ARKITEKER、PLH Arkitekter、 Weile arkitekter に心より御礼申し上げます。東京工業大学大佛俊 泰教授よりご助言を賜りました。研究当時、東京工業大学学部生で あった須藤郁氏には、ギムナジウムの調査とデータ整理等の作業に
おいて、多大なるご協力をいただきました。ここに記して感謝申し 上げます。

注

注 1) 原文 the systems of settings within which particular systems of activities take place。文献 13 参照。日本語訳は、大野隆造, 横山ゆりか 訳：文化・建築・環境デザイン，彰国社，pp. 24-41，2008による。

注2) 本稿では就学者の呼称について、フォルケスコーレの6学年以下は「児童」、 フォルケスコーレの 7 学年以上とギムナジウムは「生徒」を用いる。

注 3) デンマークのフォルケスコーレでは、1 学級の児童生徒数は最大 28 人と 定められている。特定の条件下で 30 人まで許容される場合がある。ギムナ ジウムでは、 1 学級の生徒数は 1 学年で平均して最大 28.0 人。文献 14,15 参照。 注 4) 対象事例は、デンマークにおいて最も代表的と考えられ、長期に渡って 刊行されている建築専門誌 ARKITEKTEN, Arkitektur DK, Byggeplads. dk (2002 年以前は Byggeplads Danmark) に掲載されている事例から抽出してい る。これらの専門誌は、特色あるもしくは新しい建築や批評を、比較的多く 掲載していると考えられる。FS 校は調査後に掲載されている。

注 5) NG 校は授業料は無料であるが、設備費を生徒から徵収し、充実した施設 によって、他の高校と差別化を図っている。

注 6) デンマークの教員は複数の科目を担当することがある。フォルケスコー レの教員になるには、教員養成カレッジ等で基礎科目に加えて最低 2 つ科 目を教える能力を獲得する必要があり (文献 17)、実際に教員になった後も 通常 $2 \sim 3$ 科目を担当する。ある学校の校長によると、英語の授業は、英語 の教育を受けた教員が教えるのが理想的であるが、フォルケスコーレでは必 ずしもそうでない場合もあるとのことであった。ギムナジウムの教員になる には、大学と大学院 (修士) で、ギムナジウムにもある科目から主と副の 2 科目を専攻し (文献 18,19 ) 、教員になると 1 〜 科目程度を担当する。

注 7) デンマークのフォルケスコーレには、教員の他に、ペダゴーと呼ばれる 主に児童生徒の学校生活を支援する職員が存在する。

注 8) プレゼンテーションは、低学年では課さず主に5、6 年生以上で扱ってい る教員もいる。別の教員は、クラスの前で外国語を話すことに気後れする子 どもが多いため、概ね携帯電話を持つようになる 4 年生以上では、授業で話 す代わりに携帯電話で記録して再生する工夫をしている。人に見せる前に何 度も撮り直す児童生徒もおり、練習量が増える効果が期待されている。

注 9)A レベルは 900 ～1200words、B レベルは 700 ～1000words である。 注 10) 必ずしも教科書を使うわけではない。一方で、電子書籍を増やしたいが、 費用が高額で困難という問題も生じている。e-book (オフライン) と iBook ( オンライン) のどちらを好むかは、教員によって異なる。

注 11）当該教員の自治体では、2009 年頃に教員 2 名がアメリカで協同学習 (cooperative learning) の研修を受け、帰国後に自治体の教員に講習を行 っている。協同学習には様々な定義があるが、01sen と Kagan (1992) は、学 習者がグループ内で情報交換の恩恵を受け、自分の学習に責任を持ち、意欲 的に他者の学びを高めるために体系化されたグループ学習活動としている。 文献 20 参照。

注 12）国のカリキュラムは詳細過ぎず、達成する目標を定めている。文献 21 , 22 参照。

注 13) 2017 年から 1,2 年生も学際的な課題に取り組んでいる。

注 14）学級毎に普通教室を割り当てているギムナジウム 2 校のうち 1 校では、 ヒアリング調査時に、学級を重視して現在の運営方式のままにするか、科目 毎の掲示や学級が異なる生徒の交流を重視して、科目毎の教室を設ける方式 に変更するか、教員で意見交換をし始めている、という話があった。

注 15) 具体例として、ヘッドホンやオンラインポータル等が挙げられた。

注 16）言語能力を評価する指標であるヨーロッパ共通参照枠 CEFR（Common European Framework of Reference for Languages, 2001)に記述されている。 文献 24 参照。原文は、社会的に行動する者・社会的存在は social agent、 行動中心主義は action-oriented approach。日本語訳は、吉島茂他訳 : 外 国語教育 II 一外国語の学習, 教授, 評価のためのヨーロッパ共通参照枠, 朝日出版社，2004による。

注 17) 授業 OG1 は、閉じられた教室に隣接した、コモンコアのオープンな教室 のみが使用された。

\section{参考文献}

1) Ministry of Education, Culture, Sports, Science and Technology: Courses of Study for Elementary School, https://www. mext. go. jp/ content/1413522_001.pdf, 2017 (accessed 2020.9.2) (in Japanese) 文部科学省：小学校学習指導要領 (平成 29 年告示), 2017 (2020.9.2 参照) 
2) Ministry of Education, Culture, Sports, Science and Technology: Courses of Study for Lower Secondary School, https://www. mext. go. jp/ content/1413522_002.pdf, 2017 (accessed 2020.9.2) (in Japanese) 文部科学省：中学校学習指導要領 (平成 29 年告示), 2017 (2020.9.2 参照)

3) Ministry of Education, Culture, Sports, Science and Technology: Courses of Study for High School, https://www. mext. go. jp/ content/1384661_6_1_3.pdf, 2018 (accessed 2020.9.2) (in Japanese) 文部科学省 : 高等学校学習指導要領 (平成 30 年告示), 2018 (2020.9.2 参照)

4)ETS: TOEFL iBT Test and Score Data Summary 2019, https://www. ets. org/s/toefl/pdf/94227_unlweb. pdf, 2020 (accessed 2020.9.2)

5) Undervisningsministeriet: Skolebyggeri nu og i fremtiden, -gymnasier -hf-kurser -vuc' er, Undervisningsministeriet, http://static. uvm. dk/ Publikationer/1999/skolebyg/, 1998.8 (accessed 2020.9.2)

6) Ito, S. : Activities and patterns of space use in Danish Folkeskoler, Journal of Architecture, Planning and Environmental Engineering (Transactions of AIJ), No. 549, pp. 145-152, 2001.11 (in Japanese) 伊藤俊介：デンマークのフォルケスコーレにおける学習活動と空間の使わ れ方について, 日本建築学会計画系論文集, No. 549, pp. 145-152, 2001.11

7) Ito, S. : Changing Concepts of Open-plan Schools: Examples of Danish Schools, Summaries of Technical Papers of Annual Meeting, Architectural Institute of Japan, E-1, pp. 87-88, 2004.7(in Japanese) 伊藤俊介：デンマークの学校建築にみるオープンプランの変容, 日本建築 学会大会学術講演梗概集, E-1, pp. 87-88, 2004.7

8) Tachibana, M. , Fujii, Y., Yasuda, K. and Miyamoto, F. : Spatial Composition and Use of Common Cores in Danish Gymnasier, Journal of Architecture and Planning (Transactions of AIJ), No. 775, pp. 18411851, 2020. 9 (in Japanese)

立花美緒, 藤井佳人, 安田幸一, 宮本文人 : デンマークのギムナジウムに おけるコモンコアの空間構成と使われ方，日本建築学会計画系論文集， No. 775 , pp. 1841-1851, 2020.9

9) Baba, Y. and Miyamoto, F. : Planning of English Classrooms and Learning Activities in Elementary Schools, Summaries of Technical Papers of Annual Meeting, Architectural Institute of Japan, E-1, pp. 351-352, 2009.7 (in Japanese) 馬場勇輝, 宮本文人：小学校の英語活動における教室利用と授業展開， 日本建築学会大会学術講演梗概集，E-1，pp. 351-352，2009.7

10) Morita, M. and Yanagisawa, K. : Analysis on the Space Utilization from the View Point of Grade and Subjects -Studies on the Space and Place of Gunma Kokusai Academy Part1-, Journal of Architecture and Planning (Transactions of AIJ), No.645, pp. 2329-2337, 2009. 11 (in Japanese)

森田舞，柳澤要：学年・教科別の空間利用に関する分析・考察 -ぐんま国 際アカデミーにおける空間・場の使われ方に関する調査研究 その $1-$, 日本建築学会計画系論文集，No.645, pp. 2329-2337, 2009. 11

11) Morita, M. and Yanagisawa, K. : Analysis on the Space Layout and Field of Children's Activities from the View Point of Grade -Studies on the Space and Place of Gunma Kokusai Academy Part2-, Journal of Architecture and Planning (Transactions of AIJ), No.660, pp. 305-312, 2011.2 (in Japanese)

森田舞, 柳澤要 : 学年別の空間レイアウトと児童の行動領域に関する分析 ・ 考察一ぐんま国際アカデミーにおける空間・場の使われ方に関寸る調査研究 その 2 -, 日本建築学会計画系論文集, No. 660, pp. 305-312, 2011.2

12) Kurakazu, R. and Ueno, J. : The Actual Conditions of Pupils' Learning and Living Activities in the Public Primary Schools, Journal of Architecture, Planning and Environmental Engineering (Transactions of AIJ), No. 520, pp. 139-144, 1999.6 (in Japanese) 倉斗綾子, 上野淳：小学校における児童の一日の学習・生活活動の実態, 日本建築学会計画系論文集 , No. 520, pp. 139-144, 1999.6

13) Rapoport, A. : Culture, Architecture, and Design, Locke Science Publishing Company, Inc., pp. 18-35, 2005

14) Ministry of Children and Education: The Folkeskole Classes \& Class Teacher, https://eng. uvm. dk/primary-and-lower-secondary-education/ the-folkeskole/classes-and-class-teacher, 2018. 3 (accessed 2020.9.2)

15) Undervisningsministeriet: Evaluering af det fleksible klasseloft på 28 elever $i$ de gymnasiale uddannelser, https://www. uvm. dk/-/media/ filer/uvm/udd/gym/pdf18/mar/180306-evaluering-af-det-fleksible- klasseloft-rapport-fra-epinion. pdf, 2018.2 (accessed 2019.2.9)

16)Kim Dirckinck-Holmfeld: Houses of learning, ARKITEKTUR DK, 2-2003, pp. 134-148, 2003.2

17) Uddannelses- og Forskningsministeriet: Bekendtgørelse om uddannelsen til professionsbachelor som lærer i folkeskolen, https://www. retsinformation. dk/eli/lta/2015/1068, 2015.9 (accessed 2020.11.4)

18) Uddannelses- og Forskningsministeriet: Retningslinjer for universitetsuddannelser rettet mod undervisning i de gymnasiale uddannelser samt undervisning i gymnasiale fag i eux-forløb, https://www. retsinformation. dk/eli/retsinfo/2018/9698, 2018. 8 (accessed 2020.11.4)

19) Uddannelses- og Forskningsministeriet: Bekendtgørelse om universitetsuddannelser tilrettelagt på heltid (uddannelsesbekendtgørelsen), https://www. retsinformation. dk/eli/ $1 \mathrm{ta} / 2020 / 20$, 2020. 1 (accessed 2020.11.4)

20)01sen, R. and Kagan, K. : About Cooperative Learning, Cooperative Language Learning, Kessler, C., ed., Prentice Hall Regents, pp. 1-30, 1992

21)Børne- og Undervisningsministeriet: Engelsk-Læseplan 2019 2. udgave, https://emu. dk/sites/default/files/2020-09/GSK_læseplan_Engelsk_2020. pdf, n. d. (accessed 2020.10.20)

22) Børne- og Undervisningsministeriet: Læreplaner for stx, https://www. uvm. dk/-/media/filer/uvm/gym-laereplaner-2017/samledelaereplaner-fordelt-paa-studieretninger/samlede-laereplaner---stx ${ }^{---}$ endelige-version-ua. pdf, n. d. (accessed 2021.9.6)

23) Børne- og Undervisningsministeriet: Bekendtgørelse om projektopgaven i folkeskolens 9. klasse, https://www. retsinformation. $\mathrm{dk} / \mathrm{eli} / 1 \mathrm{ta} / 2019 / 918$, 2019.9 (accessed 2020.11.5) 24) Council of Europe: Common European Framework of Reference for Languages: Learning, teaching, assessment, Cambridge University Press, https://rm. coe. int/1680459f97, 2001.2 (accessed 2020.11.10)

25) Sudo, K. , Tachibana, M. and Miyamoto, F. : English lessons and school behavior settings in Denmark and Finland, Summaries of Technical Papers of Annual Meeting, Architectural Institute of Japan, E-1, pp. 191-192, 2016.7 (in Japanese) 須藤郁, 立花美緒, 宮本文人：北欧の学校における英語の授業展開と行動 場面, 日本建築学会大会学術講演梗概集, E-1, pp. 191-192, 2016. 7 26) Tachibana, M. : English Lessons and Systems of Settings in Danish Folkeskole, Summaries of Technical Papers of Annual Meeting, Architectural Institute of Japan, E-1, pp. 443-444, 2018.7 (in Japanese) 立花美緒：デンマークの小中学校における英語授業活動のセッティングの システム，日本建築学会大会学術講演梗概集， E-1，pp. 443-444，2018.7 


\title{
ENGLISH LESSON ACTIVITIES AND SYSTEMS OF SETTINGS IN DANISH SCHOOLS
}

\author{
Mio TACHIBANA ${ }^{* 1}$, Koichi YASUDA ${ }^{* 2}$ and Fumihito MIYAMOTO*3 \\ ${ }^{* 1}$ Assist. Prof., School of Environment and Society, Tokyo Institute of Technology, M.Eng. \\ * 2 Prof., School of Environment and Society, Tokyo Institute of Technology, Ph.D. \\ * ${ }^{3}$ Prof. Emeritus, Tokyo Institute of Technology, Dr.Eng.
}

Amended curriculum guidelines have been implemented sequentially since 2020 in Japan. English education is encouraged to change while writing this paper. Consistent English learning from primary school to upper secondary school is emphasized in the new guidelines. They promote the well-balanced development of four skills; listening, reading, speaking, and writing. Although we cannot say that we have completely gotten away from the traditional teaching method so far, such as the grammar-translation method, teachers and schools have been trying to reform English education and are reaching a turning point. Thus, it is vital and urgent to examine learning environments that support new English lessons. In Denmark, the total and section score means of TOEFL iBT is high. Student-centered learning and various learning forms have been explored since the 1970s. Examining the relationship between English lesson activities and settings in Danish schools is thought to offer numerous suggestions for designing learning environments that will support future English lessons not only in Japan but also in other countries where students learn English as a second language.

This study investigated English lessons and physical settings in ten schools in Denmark. First, English education and space used in English lessons were examined by interviews with teachers. At primary and lower secondary schools, we found that the activities of English lessons spread to the outdoor space and out of the schools. They sometimes went to the town, museums, and theaters in English lessons. It was intended to connect English knowledge to real life. At secondary schools, enough options of space type and size and adequate open spaces where students learned gave teachers satisfaction with school facilities. Language teachers' rooms were well-received because they could discuss lessons and students easily and support each other.

Next, behavior observations of students and teachers in fifteen English lessons were conducted. Group work was observed frequently. It was considered important to increase students' engagement and to develop the competency to solve problems in collaboration. In addition to learning English, students were doing something by using English, such as presentations, essays, and small projects. The action-oriented approach was being adopted. We analyzed spatial composition in and around the classrooms, desk layout, students' space sequence, students' position, and environmental elements. At primary and lower secondary schools, there was scaled-downed space or furniture, which accommodates different and diverse children.

The fifteen English lessons' characteristics were clarified by exploring the relationship between contents, activities, and systems of settings. Regarding text comprehension or a single task throughout the class, students were allowed to go out of the classrooms during group work and to find quiet spaces where they could focus. The distance between students helps them to do discussion and speak English unselfconsciously. Regarding various contents on one topic, videos, or presentations, students and teachers tended to stay in the classroom, and the teachers kept students from being bored with ingenuity. They activated students by changing students' posture and position at the beginning of the lesson or by quite often changing the contents and elements of English lessons. 